Aquaculture Research

November 2008, Volume 39 Issue 16, Pages 1739 - 1746

http://dx.doi.org/10.1111/j.1365-2109.2008.02050.x

(c) 2008 Blackwell Publishing, Inc.
Archimer, archive institutionnelle de l'Ifremer http://www.ifremer.fr/docelec/

\title{
Changes in fatty acid and sterol composition during oogenesis in the pearl oyster Pinctada margaritifera
}

\author{
Isabelle Vahirua-Lechat ${ }^{1}$, Frédéric Laure ${ }^{2}$, Jean René LeCoz $^{3}$, Jean Pierre Bianchini ${ }^{2}$, Mereani \\ Bellais ${ }^{4} \&$ Gilles Le Moullac ${ }^{5}$
}

\footnotetext{
1 Laboratoire des Substances Naturelles, Institut Louis Malardé, Tahiti, French Polynesia

${ }^{2}$ Laboratoire de Chimie Analytique Appliquée, Université de Polynésie Française, Punaauia, Tahiti, French Polynesia

${ }^{3}$ Ifremer, Laboratoire de Physiologie des Invertébrés, Centre de Brest, Plouzané, France

${ }^{4}$ Écloserie du Service de la Perliculture, Avatoru, Rangiroa, French Polynesia

${ }^{5}$ Ifremer, Laboratoire d'Aquaculture Tropicale, Centre Océanologique du Pacifique, Tahiti, French Polynesia

*: Corresponding author : Gilles Le Moullac, email address : Gilles.Le.Moullac@ifremer.fr
}

\begin{abstract}
:
The fatty acid and sterol composition of the oyster Pinctada margaritifera during oogenesis and in eggs was analysed. No major differences were observed during oogenesis, but the egg composition was significantly different from that of gonads. The amount of saturated fatty acids was the highest in eggs and the $\mathrm{C} 16: 0$ predominant $(\mathrm{P}<5 \%)$; by contrast, the amount of 22:6(n-3) was significantly lower $(P<5 \%)$ than in gonads. No major differences were observed for the polar lipid (PL) composition during oogenesis. The main free sterols in gonads and eggs were cholesterol and brassicasterol. Among free sterols, the proportion of cholesterol diminished continuously from the beginning to the end of gonad maturation, and this decrease persisted in eggs after spawning. Cholesterol represented $40 \%$ to $55 \%$ of the sterol ester encountered in gonad and eggs. This study allowed us to investigate the fatty acid and sterol composition during oogenesis of the pearl oyster P. margaritifera, leading to a clearer understanding of the nutritional requirements of pearl oyster during the reproduction process.
\end{abstract}




\section{Introduction}

The rapid expansion of the cultured pearl industry in French Polynesia relies on natural spat collection from a number of atolls: however, uncontrolled practices have caused ecological and economic problems. For example, transfer of seed oysters between islands has caused the dissemination of anemones which have colonized oysters under culture. The production of seed oysters in a hatchery would limit such problems and enable a production of standard quality seed oysters. Therefore, control of reproduction is essential in any hatchery program and requires a comprehensive understanding of qualitative and quantitative nutritional requirements.

In French Polynesia, Pinctada margaritifera undergoes continuous gametogenesis because trophic conditions and temperature are favorable year round, with as a consequence, a relatively short maturation period of about 1 to 2 months (Pouvreau et al., 2000). The relative availability of mature stock has meant that basic knowledge of the qualitative aspects of nutritional requirements of $P$. margaritifera broodstock is lacking.

Among dietary components of the food given to mollusk broodstock, lipids mainly affect eggs composition (Helm et al., 1991, Utting \& Doyou, 1992). Lipids deposited in eggs during maturation play a major role as an energy source during embryonic and early larval development. During oogenesis, oocytes acquire their lipid reserves directly from the food (Beninger et al., 1991) and by transfer from muscle reserves and digestive gland (Barber \& Blake, 1985, Napolitano \& Ackman, 1993). In Pecten maximus, fatty acid and sterol composition of neutral lipids in gonads and oocytes are strongly influenced by diet during the reproductive process (Delaunay et al., 1993, Soudant et al., 1996). Marine mollusks cannot synthesize polyunsaturated fatty acids (PUFA) and sterols and must acquire them from ingested particulate matter. Most of these nutrients are precursors of membranes and play a role in metabolic regulations. PUFA with 20 and 22 carbons and more than three double bonds are essential for the survival and growth of mollusks (Trider \& Castell, 1980, Langdon \& Waldock, 1981, Uki et al., 1986). The ability to elongate and desaturate $18: 3 n-3$ to produce $20: 5 n-3$ and $22: 6 n-3$ is limited in mollusks (Waldock \& Holland, 1984, De Moreno et al., 1976, Delaunay et al., 1993).

The objectives of this study was to describe the accumulation of fatty acids and sterols of neutral and polar fractions in the gonad and eggs during oogenesis. Since oogenesis is a continuous process between the beginning of maturation and spawning, the sampled females were classified according to the degree of development of their gonad. This study will thus determine the changes in levels of neutral and polar fractions of lipids in the gonads during maturation.

\section{Material and methods}

\subsection{Sample preparation}

Adult $P$. margaritifera were collected in Rangiroa lagoon in November. Female were selected by biopsy of the gonad and their maturity index was determined by macroscopic observations according to Pouvreau (1999) based on the observations of Tranter (1958). The selected females were opened and the visceral mass dissected. One piece of gonad from each female was excised from the gonadal mass located at the intersection of the byssus gland and the pearl pocket (Fougerousse \& Herbaut, 1994). Each part of gonad was put in $6 \mathrm{~mL}$ chloroform-methanol $(2: 1 \mathrm{v} / \mathrm{v})$ for analysis of fatty acids and sterols and an amount of internal standard C23:0 was added.

Eggs were obtained after spawning induced by thermal shock. Female were isolated individually to collect the eggs that were washed and rinsed on $80 \mu \mathrm{m}$ and $10 \mu \mathrm{m}$ plankton mesh successively. Eggs were then filtered onto pre-ignited $\left(450^{\circ} \mathrm{C}\right) \mathrm{GF} / \mathrm{C}$ filters. The filters were then placed in tubes containing the chloroform-methanol mixture and an amount of internal standard C23:0 was added. Samples were then frozen at $-20^{\circ} \mathrm{C}$ under nitrogen.

\subsection{Analytical procedures}

Total lipids were extracted according to Folch et al. (1957). To separate neutral and polar lipids, 2:1 chloroform-methanol extracts were evaporated to dryness under vacuum. The extract was recovered and rinsed three times with $500 \mathrm{ml}$ of $98: 2$ chloroform-methanol. Neutral and polar lipids were separated chromatographically on a silica gel microcolumn $(30 \mathrm{~mm} \times 5 \mathrm{~mm}$, Kieselgel Merck, 70-230 
mesh). Neutral lipids were eluted with $10 \mathrm{ml}$ chloroform-methanol 98:2 and polar lipid with $10 \mathrm{ml}$ methanol. The fractions were collected in tapering vials.

Fatty acids

Fatty acids methyl esters were prepared by transesterification with 14\% BF3-MeOH (Sigma), and were purified by High Performance Chromatography (Waters 600 equipped with a diode array detector PDA-996 Waters). The chromatography was performed on two columns mounted in series: Modulo cart Lichrosorb $5 \mu \mathrm{m}$ DIOL Interchim $250 \times 4.0 \mathrm{~mm}$ and Modulo cart Lichrospher $5 \mu \mathrm{m}$ Silice Interchim $250 \times 4.0 \mathrm{~mm}$. Separation of fatty acids methyl esters was made using a gradient program elution with hexane and hexane-isopropanol,(90:10, vol:vol) at $1 \mathrm{ml} / \mathrm{min}$ of flow.

Three fractions were collected. The second fraction collected from 6.5 to 13.5 min contained fatty acids esters which were analyzed using a gas chromatograph (VARIAN GC-3800, Les Ulis, France) equipped with a flame ionisation detector (FID) and a split/splitless 1079 VARIAN injector, two capillary columns mounted in series, a OV101 capillary guard column (J\&W scientific) and a DB-Wax capillary column (J\&W scientific). Injector and detector temperatures were $240^{\circ} \mathrm{C}$ and $280^{\circ} \mathrm{C}$ respectively. The column temperature was programmed at $49^{\circ} \mathrm{C}$ during $2 \mathrm{~min}$, then from $49^{\circ} \mathrm{C}$ to $160^{\circ} \mathrm{C}$ at a rate of $50^{\circ} \mathrm{C} / \mathrm{min}, 160^{\circ} \mathrm{C}$ to $170^{\circ} \mathrm{C}$ at a rate of $1^{\circ} \mathrm{C} / \mathrm{min}, 170^{\circ} \mathrm{C}$ to $185^{\circ} \mathrm{C}$ at a rate of $2^{\circ} \mathrm{C}$ Imin, $185^{\circ} \mathrm{C}$ to $240^{\circ} \mathrm{C}$ at a rate of $3^{\circ} \mathrm{C} / \mathrm{min}$ and a final plateau at $240^{\circ} \mathrm{C}$ during $10 \mathrm{~min}$. Ultra High Purity Helium N55 was used as the carrier gas with a constant flow of $2 \mathrm{ml} / \mathrm{min}$. One $\mu \mathrm{l}$ of extract was injected with a splitless injection program, splitless during 1 min and split (ratio 1/50) after 1 min till the end of the run. Fatty acids esters were identified by their retention times with reference to the known standards and designated following the formula $C: X(n-Y)$ where $C$ is the number of carbon atoms, $X$ the number of double bonds and $Y$ the position of the first double bond counted from the $\mathrm{CH}_{3}$ terminal. Fatty esters quantification were determined using tricosanoic acid as internal standard.

\section{Sterols}

The esterified and free sterols were separated by high performance liquid chromatography (HPLC) in a Hewlett Packard system, equipped with a Lichrosorb $5 \mu \mathrm{m}$ Diol $250 \times 4.0 \mathrm{~mm}$ column (Interchim, France) and a diode array UV detector. Three fractions were collected:

Esterified sterols + fatty acids methyl esters + triglycerids : 1 to 4.5 min (fraction 1 )

Free sterols + free fatty acids + DG + MG : 4.5 to 9 min (fraction 2)

Diols (pavlovols) : 9 to 13 min. (fraction 3 )

A known amount of cholestane was added as an internal standard to fractions 1 and 2. Fractions 2 and 3 were put together, evaporated to dryness and dissolved in $80 \mu$ of hexane for injection into GC. The esterified sterol fraction 1 was evaporated to dryness and transesterified with $2 \mathrm{ml}$ of methoxide $(\mathrm{MeONa})$ for $2 \mathrm{~h}$ at ambient temperature. The sterols thus were extracted in hexane, evaporated to dryness, dissolved in $80 \mu \mathrm{l}$ of toluene and injected directly into GC. The methylated and free sterols were analyzed with a Hewlett Packard gas chromatograph equipped with a Restek RTX-65, $15 \mathrm{~m} \mathrm{x}$ $0.25 \mathrm{~mm}$ ID $\times 0.25 \mu \mathrm{m}$ film thickness capillary column, a flame ionisation detector (FID) $250^{\circ} \mathrm{C}$ and a split injector $250^{\circ} \mathrm{C}$. Helium gas vector pressure was fixed to $100 \mathrm{kPa}$ at the front of the column. The column temperature was programmed at $90^{\circ} \mathrm{C}$ for $2 \mathrm{~min}$, then from $90^{\circ} \mathrm{C}$ to $170^{\circ} \mathrm{C}$ at a rate $49.9^{\circ} \mathrm{C}$ $/ \mathrm{min}$, at $170^{\circ} \mathrm{C}$ during $1 \mathrm{~min}, 170^{\circ} \mathrm{C}$ to $260^{\circ} \mathrm{C}$ at a rate of $5^{\circ} \mathrm{C} / \mathrm{min}, 260^{\circ} \mathrm{C}$ to $280^{\circ} \mathrm{C}$ at a rate of $2^{\circ} \mathrm{C}$ Imin and a final plateau at $280^{\circ} \mathrm{C}$ for $5 \mathrm{~min}$. One $\mu \mathrm{l}$ of extract was injected with a splitless injection program, splitless during $1 \mathrm{~min}$ and split (ratio 1/75) after 1 min until the end of the run.

\section{Statistics}

Percentage data were transformed to arcsine values for statistical analysis. One way analysis was used to assess significant differences at the level of $p<0.05$. The Student-Newman-Keuls test was used as post hoc test. 


\section{Results}

\subsection{Fatty acids in the gonads and eggs}

\subsubsection{Fatty acid in the neutral lipids}

No major changes were observed in the composition of the neutral lipids during gametogenesis translated as an index of maturation (Table 1). However, there was a significant difference between the eggs and the gonad composition. There was a significant increase in total saturated fatty acids in eggs $(\mathrm{F}=8.885, \mathrm{p}=0.0006, \mathrm{df}=4)($ Table 1$)$. This increase of the total saturated fatty acids in eggs is partly due to higher contents in 16:0 of the eggs (Fig. 1). Among monounsaturated, the proportion of $(\mathrm{n}-9)$ was significantly higher in gonad than in eggs $(\mathrm{F}=3.663, \mathrm{p}=0.0251, \mathrm{df}=4)(\mathrm{Table} 1)$. The total of PUFA was significantly lower in eggs than in gonad $(F=3.083, p=0.0443, d f=4)($ Table 1$)$. The decrease of PUFA in eggs was mainly due to the significant decrease of the $(n-3)(F=5.653, p=0.0044$, $\mathrm{df}=4)($ Table 1$)$ and especially of 22:6(n-3) (Fig. 1).

The $(n-3 /(n-6)$ ratio also decreased significantly in eggs compared to the gonad $(F=9.094, p=0.0006$, $\mathrm{df}=4)($ Table 1$)$. Lastly, the 22:6/20:5 $(n-3)$ ratio decreased significantly in eggs compared to the gonad $(F=3.353, p=0.0357, d f=4)($ Table 1$)$.

\subsubsection{Fatty acid in the polar lipids}

No significant changes were observed in the fatty acid composition of the polar lipids during gametogenesis (Table 2). There was a significant difference between the eggs and the gonad composition. There was a significant increase in total saturated fatty acids in eggs ( $F=4.226$, $\mathrm{p}=0.0138, \mathrm{df}=4)($ Table 2$)$. This increase of the total saturated fatty acids in eggs is partly due to higher contents in 18:0 of the eggs (Fig. 2). The total of PUFA was significantly lower in eggs than in gonad $(F=5.016, p=0.0068, d f=4)($ Table 2$)$. The decrease of PUFA in eggs was mainly due to the significant decrease of the $(n-3)(F=5.107, p=0.0063$, df $=4)($ Table 2$)$ and especially of 22:6(n-3) (Fig. 1).

The 22:6/20:5 (n-3) ratio changed significantly during maturation and in eggs $(F=9.328, p=0.0004, d f=$ 4) (Table 2), the Student-Newman-Keuls post hoc test determined that the value of the 22:6/20:5 (n-3) ratio was significantly lower at stage 4 compared to stage 1 (Table 2) and stage 2 and the 22:6/20:5 $(n-3)$ ratio in eggs was significantly lower compared to the gonad (Table 2). The 22:5/20:4 (n-6) ratio also decreased significantly in eggs $(F=6.401, p=0.0022$, $d f=4)($ Table 2$)$.

\subsection{Sterols in the gonads and eggs}

\section{Sterol esters}

The major sterol ester present in gonads and eggs was the cholesterol ester representing about 40 to $55 \%$ of the sterol esters. Cholesterol ester diminished gradually significantly during the maturation process and was the lowest at stage 3 and 4, while in the eggs, cholesterol ester increased significantly ( $F=6.328, p=0.0014, d f=4)$ (Fig. 3).

Free sterols

Cholesterol and brassicasterol were the major free sterols present in the gonad and the eggs (Fig. 4). Among all the free sterols detected and quantified, the amount of cholesterol decreased significantly throughout the maturation process and the decrease was also seen in the eggs $(F=7.614, p=0.0005$, $\mathrm{df}=4)\left(\right.$ Fig.4). The level of cdihydro significantly increased in eggs $\left(F=6.63^{\circ}, p=0.0011\right)$ (Fig. 4).

\section{Discussion}

The main objective of this study was to determine the fatty acid and sterol composition of the female gonad and eggs of the pearl oyster $P$. margaritifera. During oogenesis of $P$. margaritifera, few changes were observed. The mass of gonad increased by the accumulation of reserves including lipids but the results showed that the proportions of the various neutral and polar fatty acids were stable during maturation; there was thus no preferential accumulation of certain molecules as in Pecten maximus (Duinker et al, 2004). But our results showed that the lipid compositions in gonad and eggs were 
different in $P$. margaritifera. The saturated fatty acids, neutral and polar, were more abundant in eggs than in the gonad while the amount of polyunsaturated fatty acids was lower in eggs. Difference in lipid composition between gonad and eggs were previously observed in C. gigas (Robinson, 1992) for the saturated and monounsaturated fatty acids content but not for PUFA. Change of lipid profile from gonad to eggs in $P$. margaritifera could be due to the lipid composition of tissues composing the gonad such as haemoplymph, haemocyte and membrane of the gonadic tubules. Few data are available in this field.

The major molecules present in the gonad and the oocytes were palmitic acid 16:0 and 22:6(n-3). Fatty acids 14:0, 16:0 and most unsaturated C18s were highly used during $P$. margaritifera embryo development and as such, may be good indicators of egg quality (Acosta-Salmon, 2004). The prevalence of 16:0 and 22:6(n-3) has already been described in several bivalves including Pecten maximus (Soudant et al., 1996), Crassostrea gigas (Soudant et al., 1999) and Argopecten purpuratus (Caers et al., 1999). However the content of these 2 fatty acids was highest in $P$. margaritifera. The 22:6(n-3) plays a major role in the structure and function of the cellular membranes involved in oogenesis and embryogenesis. Hatching rates could be associated with the content of 22:6(n-3) (Soudant, 1995). An important difference characterized in P. margaritifera was the higher level of 20:5(n-3) compared to species from temperate areas. The arachidonic acid content in $P$. margaritifera was similar with that observed in $P$. maximus (Soudant et al., 1996a). The comparison of 22:6(n$3) / 20: 5(n-3)$ and $20: 4(n-6) / 20: 5(n-3)$ ratios of the neutral and polar lipids indicated that the DHA and the EPA were selectively accumulated compared to the 20: 5(n-3). Moreover, the ratio 22:6(n$3) / 20: 5(n-3)$ would act as a nutritional indicator in $P$. maximus since the value of the ratio varies greatly according to the diet (Soudant, 1995).

Cholesterol is the major compound of sterol esters in the gonad of $P$. margaritifera as was found in $P$. maximus (Soudant, 1995). Sterols and their evolution conform with the pattern observed in other marine bivalves. Among free sterols, brassicasterol and cholesterol had similar proportions. The main change concerning the cholesterol content was a decrease during maturation. Such decrease was not thought to have resulted from food supply but probably related to maturation and egg formation. The oyster could act also by selecting or rejecting molecules specifically. Cholesterol plays a role to rigidify membrane structure and thus sterol content directly influences membrane fluidity (Irazu et al., 1988). Esterified sterols are generally considered as a reserve, and used by embryo for membrane biosynthesis.

In order to provide pearl oysters with PUFA and sterols they require during conditioning for reproduction in hatchery, it is obvious that these elements be provided by food. The requirement of pearl oyster in 20:4(n-6) and 20:5(n-3) was not high, but these fatty acids are very essential. Chatoceros $s p$. is able to provide 20:4(n-6) (Soudant et al., 1996a, Renaud et al., 1999, MartinezFernandez et al., 2006), 22:6 (n-3) is more present in T. Isochrysis (Soudant et al., 1996a, MartinezFernandez et al, 2006). The main sterols in gonad of $P$. margaritifera were cholesterol and brassicasterol which are abundant respectively in Chaetoceros calcitrans and $T$. Isochrysis (Soudant et al, 1998).

Our study allowed us to investigate the fatty acid and sterol composition of female $P$. margaritifera oyster gonads during their maturation and in oocytes. This knowledge could lead to a clearer understanding of the nutritional requirements of pearl oyster and could assist further adaptation of pearl oyster aquaculture to enhance the reproduction process. In particular, unicellular algae could provide the qualitative and quantitative nutritional needs in term of fatty acids and sterols during oogenesis of the oyster.

\section{Aknowledgements}

The authors are indebted to $\mathrm{J}$ Tiapari and $\mathrm{Y}$ Mitermite for technical assistance. This work was supported by financial aid from the Ministère de l'Outre Mer of France. We thank Dr Phillipe Soudant for his assistance for preparing this project, the Service de la Perliculture and Philippe Cabral of Gauguin Pearl for providing us with pearl oysters and Gérard Cuzon for his advice. 


\section{References}

Acosta-Salmon H. (2004) Broodstock management and egg quality of the pearl oyster Pinctada margaritifera and P. fucata. PhD Thesis, School of Marine Biology and Aquaculture, James Cook University. 142p.

Barber B.J. \& Blake N.J. (1985) Intra-organ biochemical transformation associated with oogenesis in the bay scallop, Argopecten irradians concentricus (Say), as indicated by ${ }^{14} \mathrm{C}$ incorporation. Biological Bulletin 168, 39-49.

Beninger P., Le Pennec M., Dorange G. \& Widowati I. (1991) Trophic relationships between the gonad intestinal loop and developing gametes in Pecten maximus. $8^{\text {th }}$ International Pectinid Workshop, Cherbourg.

Caers M., Coutteau P., Cure K., Morales V., Gajardo G. \&. Sorgeloos P. (1999) The Chilean scallop Argopecten purpuratus (Lamarck, 1819): I, fatty acid composition and lipid content of six organs. Comparative Biochemistry and Physiology 123B, 89-96.

Delaunay F., Marty Y., Moal J. \& Samain J.F. (1993) The effect of monospecific algal diets on growth and fatty acid composition of Pecten maximus (L) larvae. Journal of Experimental Marine Biology and Ecology 173, 163-179.

De Moreno J.E.A., De Moreno V.J. \& Brenner R.R. (1976) Lipid metabolism of the yellow clam Mesosdesma mactroides: II. Polyunsaturated fatty acid metabolism. Lipids 11, 561-566.

Duinker A., Torstensen B.E. \& Lie O. (2004) Lipid classes and fatty acid composition in female gonads of great scallops-a selective field study. Journal of Shellfisheries Research, 23, 507-514.

Fougerousse A. \& Herbaut C. (1994) Atlas anatomique de I'huître perlière Pinctada margaritifera. UPF-EVAAM.

Helm M.M., Holland D.L., Utting S.D. \& East J. (1991) Fatty acid composition of early non feeding larvae of the European flat oyster, Ostrea edulis. Journal of the Marine Biological Association of United Kingdom 71, 691-705.

Irazu C.E., Pollero R.J. \& Brenner R.R. (1988) Fitosterol effect upon microsomal membrane microviscosity of the mollusc Diplodon delodontus. Comparative Biochemistry and Physiology 89B, 465-470.

Langdon C.J. \& Waldock M.J. (1981) The effect of algal and artificial diets on the growth and fatty acid composition of Crassostrea gigas spat. Journal of the Marine Biological Association of United Kingdom 62, 431-448.

Loret P., Le Gall S., Dupuy C., Blanchot J., Pastoureaud A., Delesalle B., Caisey X. \& Jonquières G. (2000a) Heterotrophic protists as a trophic link between picocyanobacteria and the pearl oyster Pinctada margaritifera in the Takapoto lagoon (Tuamotu Archipelago, French Polynesia). Aquatic Microbial Ecology 22, 215-226,

Martinez-Fernandez E., Acosta-Salmon H. \& Southgate P.C. (2006) The nutritional value of seven species of tropical microalgae for black-lip pearl oyster (Pinctada margaritifera, L.) larvae. Aquaculture 257, 491-503.

Müller-Feuga A., Robert R., Cahu C., Robin J., Divanach P. (2003) Uses of microalgae in aquaculture. In: Stottrup J.G. \& McEvoy L.A. (Eds), Live feeds in Marine Aquaculture. Blackwell Science Ltd., Oxford, UK., pp. 252-299.

Napolitano G.E. \& Ackman R.G. (1993) Fatty acids dynamics in sea scallops Placopecten magellanicus (Gmelin) from Georges Bank, Nova Scotia. Journal of Shellfish Research 12, 267-277.

Pouvreau S. (1999) Etude et modélisation des mécanismes impliqués dans la croissance de l'huître perlière, Pinctada margaritifera, au sein de l'écosystème conchylicole du lagon de l'atoll de Takapoto (Polynésie Française). Thèse de l'Université de Rennes, 267p.

Pouvreau S., Gangnery A., Tiapari J., Lagarde F., Garnier M. \& Bodoy A. (2000) Gametogenic cycle and reproductive effort of the tropical blacklip pearl oyster, Pinctada margaritifera (Bivalvia: Pteriidae), cultivated in Takapoto atoll (French Polynesia). Aquatic Living Resources 13, 37-48.

Renaud S.M., Luong-Van Thinh \& Perry D.L. (1999) The gross chemical composition and fatty acid composition of 18 species of tropical Australian microalgae for possible use in mariculture. Aquaculture 170, 147-159.

Robinson, A. (1992) Dietary supplements for the reproductive conditioning of Crassostrea gigas kumamoto (Thunberg): II. Effects on glycogen, lipid and fatty acid content of broodstock oysters and eggs. Journal of Shellfish Research, 11, 443-447.

Soudant P. (1995) Les phospholipides et les stérols des géniteurs et des larves de coquille SaintJacques Pecten maximus (L.) relation avec la nutrition. Thèse Université de Brest, 277p. 
Soudant P., Marty Y., Moal J., Robert R., Quéré C., Le Coz J.R. \& Samain J.F. (1996a) Effect of food fatty acid and sterol quality on Pecten maximus gonad composition and reproduction process. Aquaculture 143, 361-378.

Soudant P., Moal J., Marty Y. \& Samain J.F. (1996b) Impact of the quality of dietary fatty acids on metabolism and the composition of polar lipid classes in female gonads of Pecten maximus (L.). Journal of Experimental Marine Biology and Ecology 205, 149-163.

Soudant P., Le Coz J.R., Marty Y., Moal J., Robert R. \& Samain J.F. (1998) Incorporation of microalgae sterols by scallop Pecten maximus (L.) Larvae. Comparative Biochemistry and Physiology 119A, 451-457.

Soudant P., Van Ryckeghem K., Marty Y., Moal J., Samain J.F. \& Sorgeloos P. (1999) Comparison of the lipid class and fatty acid composition between a reproductive cycle in nature and a standard hatchery conditioning of the Pacific oyster Crassostrea gigas. Comparative Biochemistry and Physiology 123B, 209-222.

Tranter D.J. (1958) Reproduction in Australian pearl oysters (Lammelibranchia). IV. Pinctada margaritifera (Linnaeus). Australian Journal of Marine and Freshwater Resources, 9, 511-525.

Trider D.J. \& Castell J.D. (1980) Effect of dietary lipids on growth, tissue composition and metabolism of the oyster (Crassostrea virginica). Journal of Nutrition 110, 1303-1309.

Uki N., Sugiura M. \& Watanabe T. (1986) Requirement of essential fatty acids in the abalone Haliotis discus hannai. Nippon Suisan Gakkaishi 52, 1013-1023.

Utting S.D. \& Doyou J. (1992) The increased utilization of egg lipid reserves following induction of triploidy in the manila clam (Tapes philippinarum). Aquaculture 103, 17-28.

Waldock M.J. \& Holland D.L. (1984) Fatty acid metabolism in young oyster, Crassostrea gigas: polyunsatutared fatty acids. Lipids $19,332-336$. 
Tables

Table 1: Categories of fatty acids and ratios of essential fatty acids in the neutral lipids of female gonads and eggs of Pinctada margaritifera (\% of total fatty acids). (mean \pm standard deviation, $n=3-5$ oysters)

\begin{tabular}{|c|c|c|c|c|c|c|c|c|c|c|}
\hline \multirow[t]{3}{*}{$\begin{array}{l}\text { Fatty acid } \\
\text { categories }\end{array}$} & \multicolumn{8}{|c|}{ gonadal maturity index } & & \\
\hline & \multicolumn{2}{|c|}{1} & \multicolumn{2}{|c|}{2} & \multicolumn{2}{|c|}{3} & \multicolumn{2}{|c|}{4} & \multicolumn{2}{|c|}{ eggs } \\
\hline & mean & SD & mean & SD & mean & SD & mean & SD & mean & SD \\
\hline TO.SAT. & $23.98^{\mathrm{B}}$ & 9.19 & $37.11^{B}$ & 3.34 & $37.46^{\mathrm{B}}$ & 2.71 & $35.74^{\mathrm{B}}$ & 5.46 & $55.51^{a}$ & 7.14 \\
\hline TO.DMA & 0.59 & 0.49 & 0.11 & 0.10 & 0.44 & 0.17 & 1.43 & 2.46 & 1.19 & 1.72 \\
\hline TO.MONO & 11.63 & 3.83 & 10.49 & 0.49 & 10.14 & 1.22 & 9.98 & 2.29 & 17.17 & 8.58 \\
\hline TO.(n-9) & $4.32^{\mathrm{b}}$ & 0.54 & $4.91^{b}$ & 0.12 & $4.76^{\mathrm{b}}$ & 0.54 & $5.27^{b}$ & 0.41 & $6.51^{\mathrm{a}}$ & 1.67 \\
\hline TO. $(n-7)$ & 3.59 & 0.83 & 4.14 & 0.18 & 3.81 & 0.58 & 3.50 & 1.33 & 4.13 & 2.56 \\
\hline TO.POLY & $53.12^{a}$ & 4.76 & $50.78^{a}$ & 2.71 & $50.79^{a}$ & 3.74 & $51.78^{a}$ & 3.37 & $34.41^{b}$ & 21.72 \\
\hline TO.(n-4) & 1.31 & 1.29 & 0.40 & 0.29 & 0.36 & 0.29 & 0.84 & 0.51 & 0.78 & 0.61 \\
\hline TO.(n-6) & 6.52 & 1.37 & 4.73 & 1.42 & 5.65 & 0.60 & 7.20 & 1.51 & 7.43 & 2.89 \\
\hline TO. $(n-3)$ & $43.22^{a}$ & 1.66 & $44.31^{a}$ & 4.10 & $43.16^{a}$ & 3.17 & $41.87^{a}$ & 4.71 & $22.21^{\mathrm{b}}$ & 17.10 \\
\hline TO. NMI & 1.98 & 1.62 & 1.18 & 0.24 & 1.47 & 0.38 & 1.60 & 0.98 & 3.89 & 2.61 \\
\hline$(n-3) /(n-6)$ & $6.79^{\mathrm{a}}$ & 1.94 & $7.97^{\mathrm{a}}$ & 0.76 & $7.69^{a}$ & 0.68 & $6.09^{a}$ & 1.69 & $2.75^{b}$ & 1.94 \\
\hline $22: 6 / 20: 5(n-3)$ & $7.60^{\mathrm{a}}$ & 0.62 & $7.73^{\mathrm{a}}$ & 0.43 & $7.57^{\mathrm{a}}$ & 0.71 & $7.02^{a}$ & 1.53 & $5.32^{b}$ & 0.65 \\
\hline $22: 5 / 20: 4(n--6)$ & 1.08 & 0.42 & 0.71 & 0.09 & 0.66 & 0.09 & 0.62 & 0.22 & 0.38 & 0.11 \\
\hline $20: 4(n-6) / 20: 5(n-3)$ & 0.23 & 0.34 & 0.22 & 0.14 & 0.31 & 0.04 & 0.42 & 0.18 & 0.72 & 0.42 \\
\hline
\end{tabular}

Within each line, homogenous groups are marked with the same alphabetic letters.

Table 2: Categories of fatty acids and ratios of essential fatty acids in the polar lipids of female gonads and eggs of Pinctada margaritifera (\% of total fatty acids) (mean \pm standard deviation, $n=3-5$ oysters)

\begin{tabular}{|c|c|c|c|c|c|c|c|c|c|c|}
\hline \multirow[t]{3}{*}{$\begin{array}{ll}\text { Fatty } & \text { acic }\end{array}$} & \multicolumn{8}{|c|}{ gonadal maturity index } & \multirow{2}{*}{\multicolumn{2}{|c|}{ eggs }} \\
\hline & \multicolumn{2}{|c|}{1} & \multicolumn{2}{|c|}{2} & \multicolumn{2}{|c|}{3} & \multicolumn{2}{|c|}{4} & & \\
\hline & mean & $\mathrm{SD}$ & mean & $\mathrm{SD}$ & mean & $\mathrm{SD}$ & mean & $\mathrm{SD}$ & mean & SD \\
\hline TO.SAT. & $18.87^{b}$ & 4.14 & $16.94^{b}$ & 1.70 & $17.48^{b}$ & 0.69 & $18.40^{b}$ & 1.02 & $38.31^{a}$ & 23.49 \\
\hline TO.DMA & 5.24 & 5.88 & 7.75 & 5.73 & 5.38 & 4.16 & 10.61 & 2.29 & 2.48 & 1.89 \\
\hline TO.MONO & 10.97 & 3.01 & 10.47 & 0.64 & 10.75 & 1.04 & 10.31 & 0.78 & 13.60 & 3.52 \\
\hline TO.(n-9) & 4.21 & 2.62 & 4.57 & 2.14 & 4.26 & 1.63 & 5.59 & 1.81 & 5.47 & 2.31 \\
\hline TO.(n-7) & 2.21 & 1.17 & 1.75 & 0.50 & 1.67 & 0.43 & 1.95 & 0.59 & 3.88 & 2.68 \\
\hline TO.POLY & $63.72^{\mathrm{a}}$ & 5.84 & $58.85^{a}$ & 2.27 & $58.99^{\mathrm{a}}$ & 2.09 & $59.05^{a}$ & 1.92 & $39.89^{b}$ & 20.55 \\
\hline TO.(n-4) & 4.33 & 4.17 & 1.52 & 0.36 & 2.11 & 0.98 & 1.93 & 0.44 & 1.01 & 0.51 \\
\hline TO.(n-6) & 10.95 & 2.87 & 10.35 & 0.36 & 10.16 & 0.33 & 10.53 & 0.55 & 8.37 & 3.14 \\
\hline TO.(n-3) & $41.18^{\mathrm{a}}$ & 4.97 & $40.90^{\mathrm{a}}$ & 3.15 & $40.38^{a}$ & 1.35 & $40.48^{\mathrm{a}}$ & 1.58 & $25.46^{b}$ & 14.30 \\
\hline TO. NMI & 7.13 & 1.97 & 5.90 & 0.82 & 6.18 & 0.34 & 5.95 & 0.34 & 4.87 & 2.85 \\
\hline$(n-3) /(n-6)$ & 4.01 & 1.26 & 3.96 & 0.40 & 3.98 & 0.14 & 3.85 & 0.25 & 2.84 & 0.84 \\
\hline $22: 6 / 20: 5(n-3)$ & $6.81^{\mathrm{a}}$ & 0.48 & $6.71^{\mathrm{a}}$ & 0.48 & $6.42^{\mathrm{ab}}$ & 0.73 & $5.61^{b}$ & 0.43 & $4.33^{c}$ & 0.01 \\
\hline $22: 5 / 20: 4(n--6)$ & $0.33^{\mathrm{a}}$ & 0.03 & $0.34^{\mathrm{a}}$ & 0.05 & $0.32^{\mathrm{a}}$ & 0.02 & $0.31^{\mathrm{a}}$ & 0.01 & $0.16^{b}$ & 0.14 \\
\hline $20: 4(n-6) / 20: 5(n-3)$ & 1.34 & 0.71 & 1.04 & 0.19 & 1.05 & 0.12 & 1.02 & 0.14 & 1.01 & 0.02 \\
\hline
\end{tabular}

Within each line, homogenous groups are marked with the same alphabetic letters. 
Fig 1

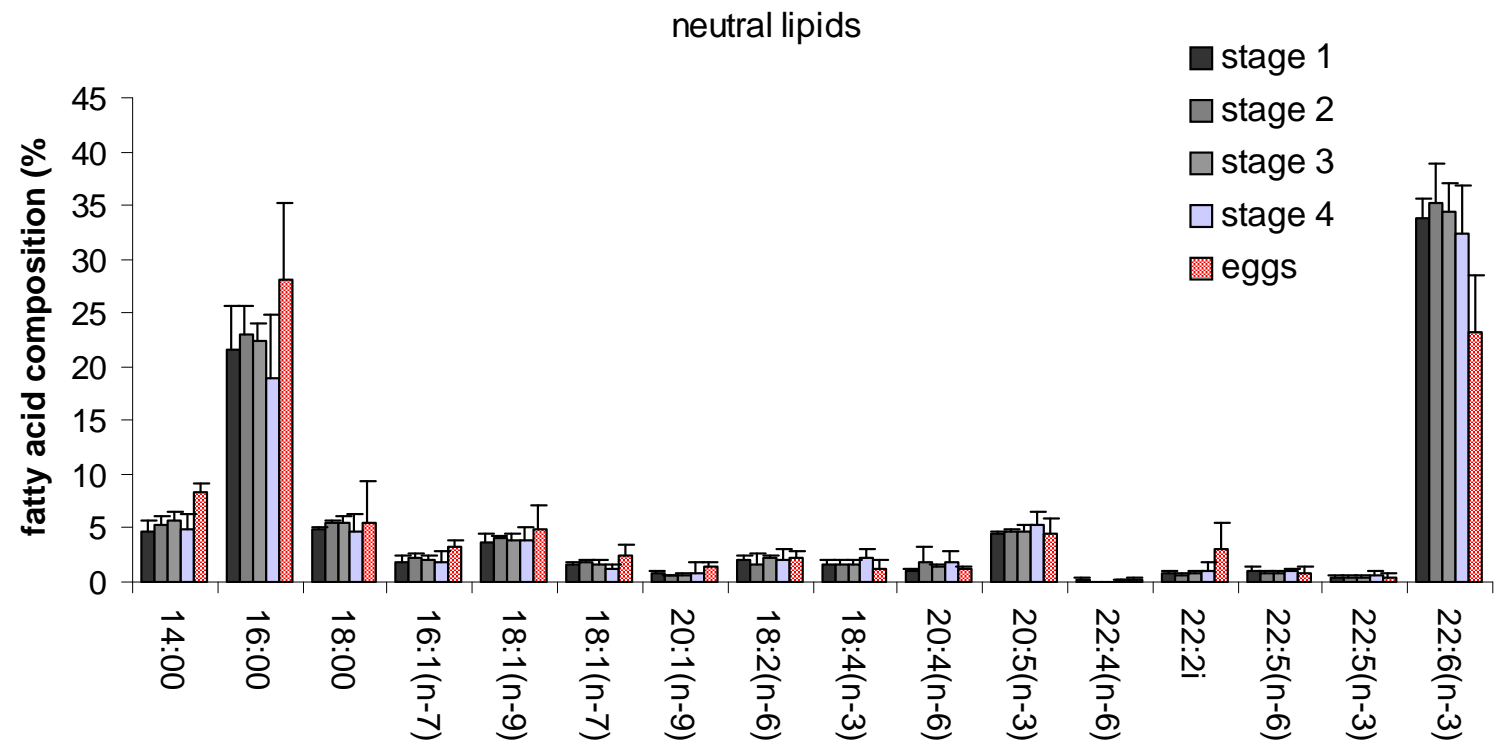

Figure 1: Simplified composition of neutral fatty acids in female gonads and eggs. The results are expressed as the percentage of total fatty acids of the fraction. (mean \pm standard deviation, $n=3-5$ oysters).

Fig 2

polar lipids

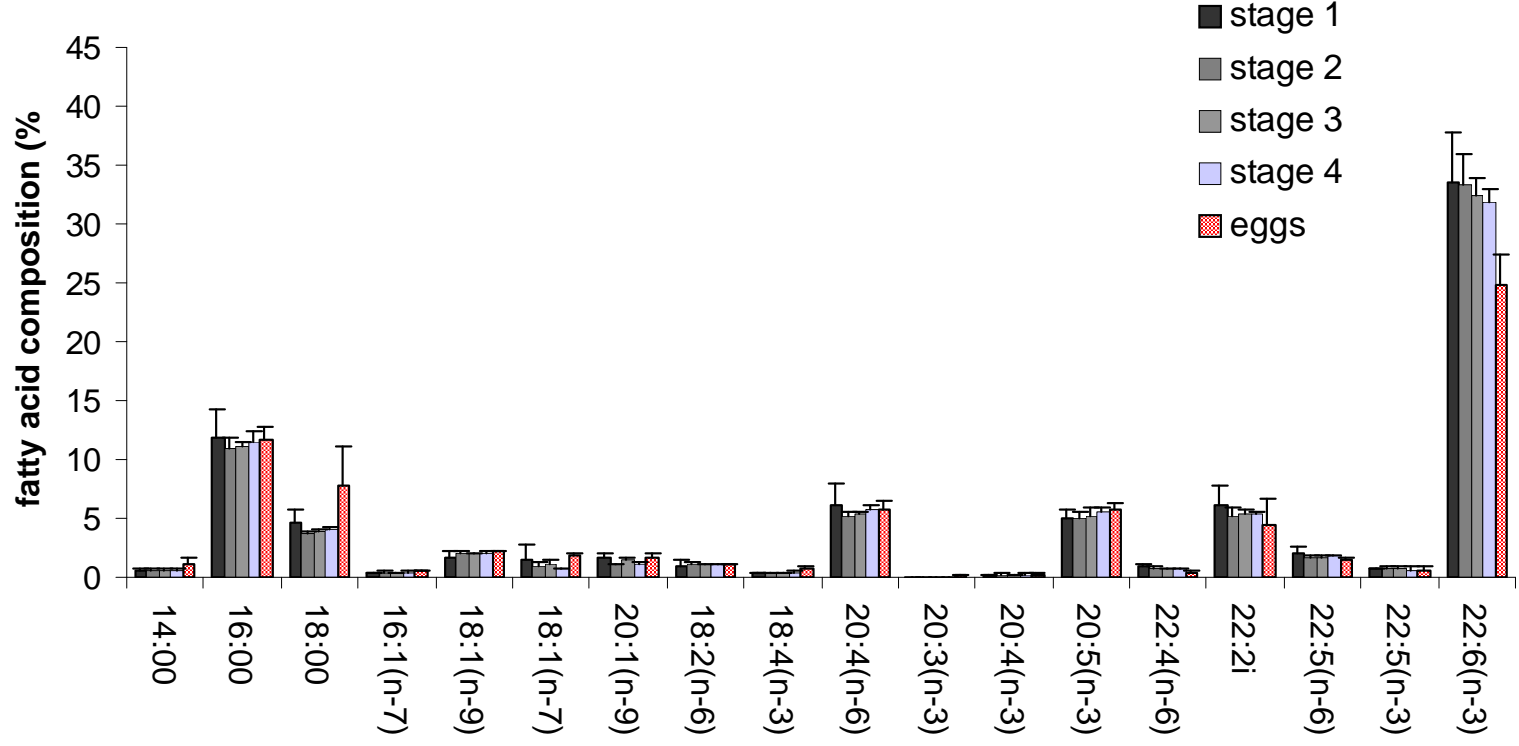

Figure 2: Simplified composition of polar fatty acids in in female gonads and eggs. The results are expressed as the percentage of total fatty acids of the fraction. (mean \pm standard deviation, $n=3-5$ oysters). 
Fig 3

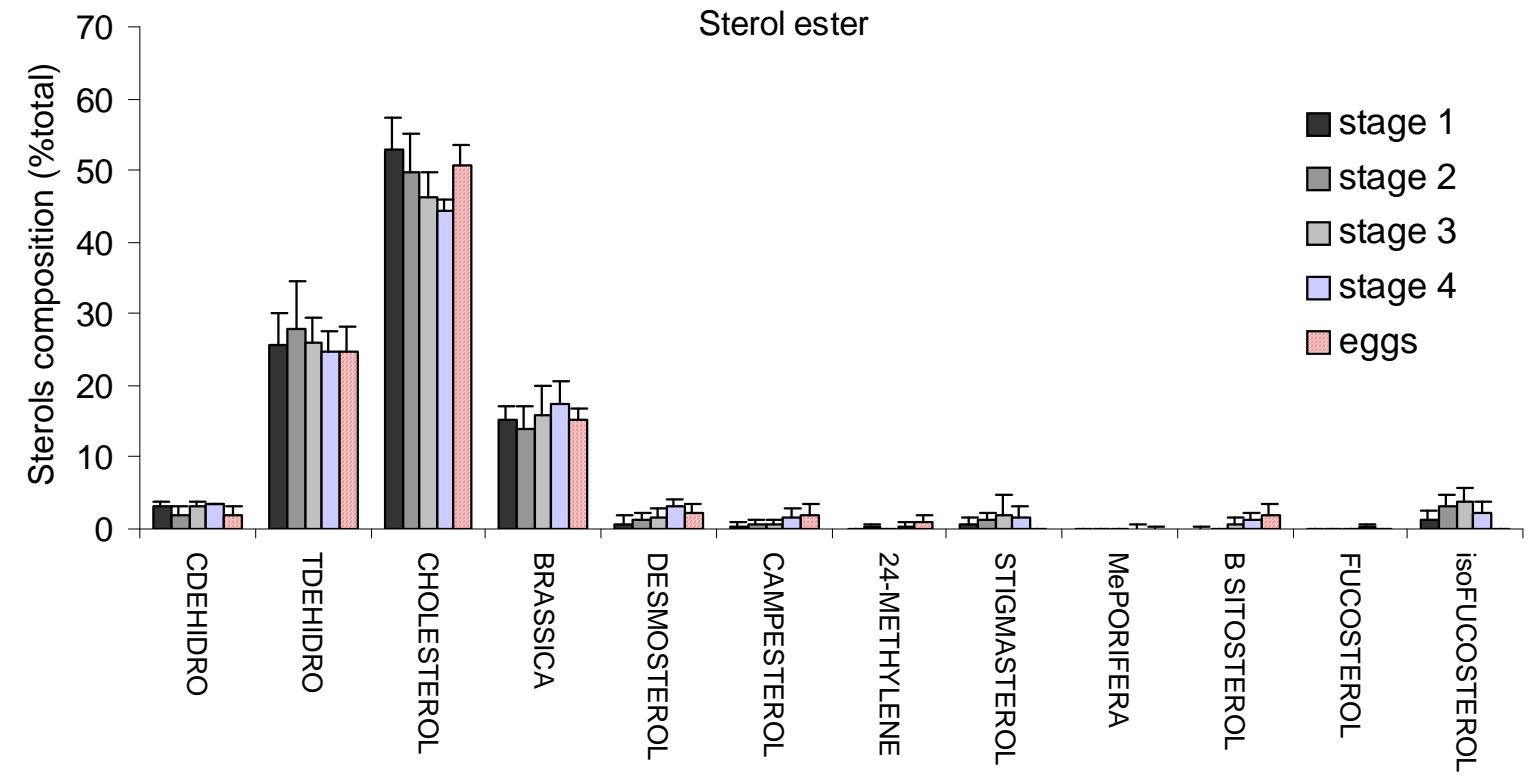

Figure 3: Composition of sterol esters in female gonads and eggs. The results are expressed as the percentage of total free sterol of the fraction. (mean \pm standard deviation, $n=3-5$ oysters).

Fig 4

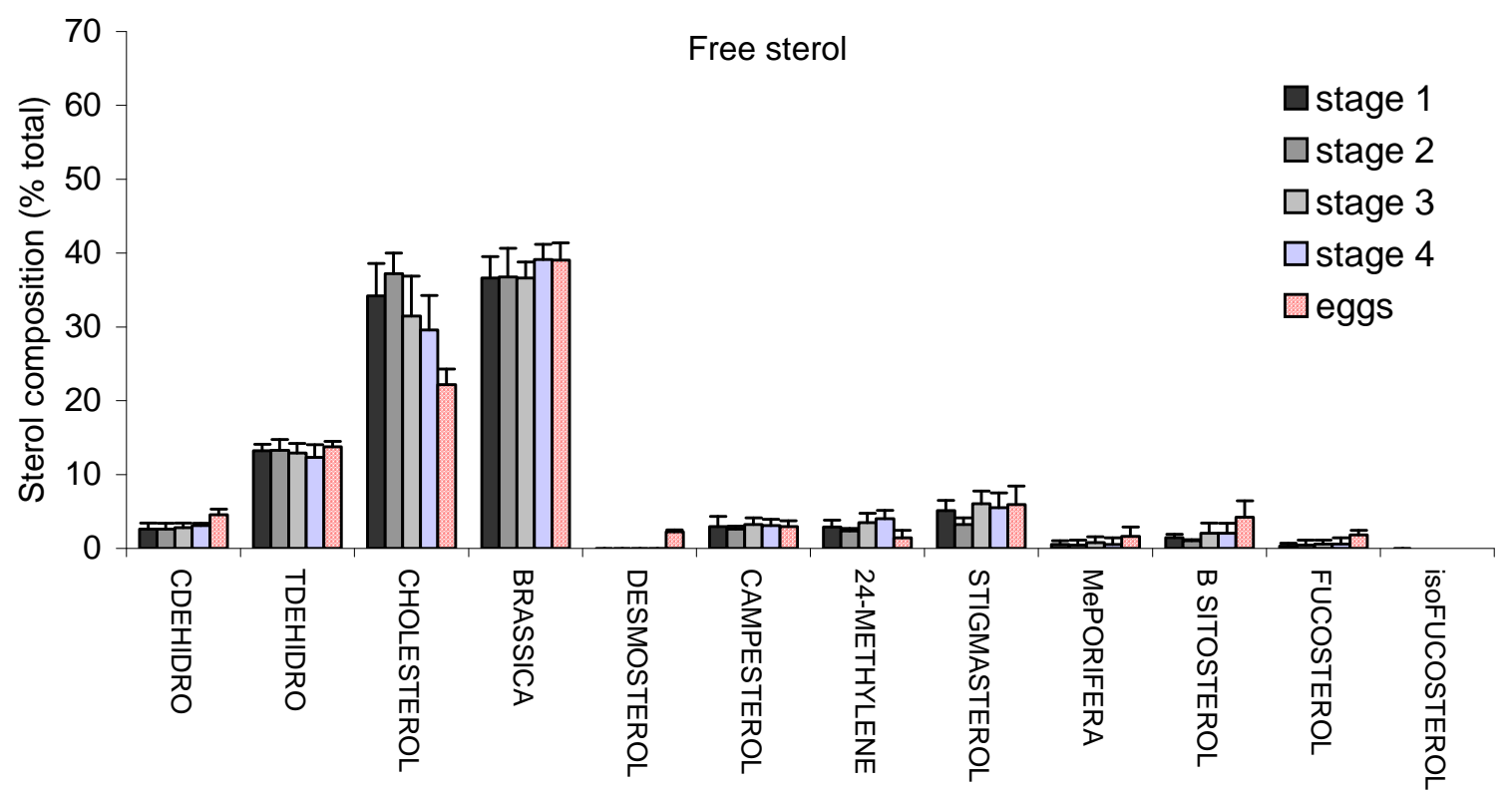

Figure 4: Composition of free sterols in female gonads and eggs. The results are expressed as the percentage of total sterol ester of the fraction. (mean \pm standard deviation, $n=3-5$ oysters). 